\title{
Nitrous oxide and methane in two tropical estuaries in a peat-dominated region of northwestern Borneo
}

\author{
Denise Müller ${ }^{1}$, Hermann W. Bange ${ }^{2}$, Thorsten Warneke ${ }^{1}$, Tim Rixen ${ }^{3,4}$, Moritz Müller $^{5}$, Aazani Mujahid ${ }^{6}$, and \\ Justus Notholt ${ }^{1,7}$ \\ ${ }^{1}$ Institute of Environmental Physics, University of Bremen, Otto-Hahn-Allee 1, 28359 Bremen, Germany \\ ${ }^{2}$ GEOMAR Helmholtz Centre for Ocean Research Kiel, Düsternbrooker Weg 20, 24105 Kiel, Germany \\ ${ }^{3}$ Leibniz Center for Tropical Marine Ecology, Fahrenheitstr. 6, 28359 Bremen, Germany \\ ${ }^{4}$ Institute of Geology, University of Hamburg, Bundesstr. 55, 20146 Hamburg, Germany \\ ${ }^{5}$ Swinburne University of Technology, Faculty of Engineering, Computing and Science, Jalan Simpang Tiga, \\ 93350 Kuching, Sarawak, Malaysia \\ ${ }^{6}$ Department of Aquatic Science, Faculty of Resource Science \& Technology, University Malaysia Sarawak, \\ 94300 Kota Samarahan, Sarawak, Malaysia \\ ${ }^{7}$ MARUM Center for Marine Environmental Sciences at the University of Bremen, Leobener Str., 28359 Bremen, Germany
}

Correspondence to: Denise Müller (dmueller@iup.physik.uni-bremen.de)

Received: 5 January 2016 - Published in Biogeosciences Discuss.: 18 January 2016

Revised: 29 March 2016 - Accepted: 12 April 2016 - Published: 26 April 2016

\begin{abstract}
Estuaries are sources of nitrous oxide $\left(\mathrm{N}_{2} \mathrm{O}\right)$ and methane $\left(\mathrm{CH}_{4}\right)$ to the atmosphere. However, our present knowledge of $\mathrm{N}_{2} \mathrm{O}$ and $\mathrm{CH}_{4}$ emissions from estuaries in the tropics is very limited because data are scarce. In this study, we present first measurements of dissolved $\mathrm{N}_{2} \mathrm{O}$ and $\mathrm{CH}_{4}$ from two estuaries in a peat-dominated region of northwestern Borneo. Two campaigns (during the dry season in June 2013 and during the wet season in March 2014) were conducted in the estuaries of the Lupar and Saribas rivers. Median $\mathrm{N}_{2} \mathrm{O}$ concentrations ranged between 7.2 and $12.3 \mathrm{nmol} \mathrm{L}^{-1}$ and were higher in the marine end-member $\left(13.0 \pm 7.0 \mathrm{nmol} \mathrm{L}^{-1}\right) . \mathrm{CH}_{4}$ concentrations were low in the coastal ocean $\left(3.6 \pm 0.2 \mathrm{nmol} \mathrm{L}^{-1}\right)$ and higher in the estuaries (medians between 10.6 and $64.0 \mathrm{nmol} \mathrm{L}^{-1}$ ). The respiration of abundant organic matter and presumably anthropogenic input caused slight eutrophication, which did not lead to hypoxia or enhanced $\mathrm{N}_{2} \mathrm{O}$ concentrations, however. Generally, $\mathrm{N}_{2} \mathrm{O}$ concentrations were not related to dissolved inorganic nitrogen concentrations. Thus, the use of an emission factor for the calculation of $\mathrm{N}_{2} \mathrm{O}$ emissions from the inorganic nitrogen load leads to an overestimation of the flux from the Lupar and Saribas estuaries. $\mathrm{N}_{2} \mathrm{O}$ was negatively correlated with salinity during the dry season, which suggests a riverine source. In contrast, $\mathrm{N}_{2} \mathrm{O}$ concentrations during the
\end{abstract}

wet season were not correlated with salinity but locally enhanced within the estuaries, implying that there were additional estuarine sources during the wet (i.e., monsoon) season. Estuarine $\mathrm{CH}_{4}$ distributions were not driven by freshwater input but rather by tidal variations. Both $\mathrm{N}_{2} \mathrm{O}$ and $\mathrm{CH}_{4}$ concentrations were more variable during the wet season. We infer that the wet season dominates the variability of the $\mathrm{N}_{2} \mathrm{O}$ and $\mathrm{CH}_{4}$ concentrations and subsequent emissions from tropical estuaries. Thus, we speculate that any changes in the Southeast Asian monsoon system will lead to changes in the $\mathrm{N}_{2} \mathrm{O}$ and $\mathrm{CH}_{4}$ emissions from these systems. We also suggest that the ongoing cultivation of peat soil in Borneo is likely to increase $\mathrm{N}_{2} \mathrm{O}$ emissions from these estuaries, while the effect on $\mathrm{CH}_{4}$ remains uncertain.

\section{Introduction}

Nitrous oxide $\left(\mathrm{N}_{2} \mathrm{O}\right)$ and methane $\left(\mathrm{CH}_{4}\right)$ are greenhouse gases whose global warming potentials exceed that of carbon dioxide $\left(\mathrm{CO}_{2}\right)$ by far (a factor of 265 for $\mathrm{N}_{2} \mathrm{O}$ and 28 for $\mathrm{CH}_{4}$ on a 100-year time horizon; Myhre et al., 2013). Thus, an assessment of the natural and anthropogenic sources and sinks as well as the formation pathways of $\mathrm{N}_{2} \mathrm{O}$ and $\mathrm{CH}_{4}$ 
is essential to understand Earth's present climate variability and to predict its future development. The world's oceans, including its coastal zones, are sources of $\mathrm{N}_{2} \mathrm{O}$ and $\mathrm{CH}_{4}$ to the atmosphere and play a major role in the global budget of atmospheric $\mathrm{N}_{2} \mathrm{O}$, but only a minor role in the global budget of atmospheric $\mathrm{CH}_{4}$ (Ciais et al., 2013). Rivers and estuaries are considered hot spots for the production and emission of both $\mathrm{N}_{2} \mathrm{O}$ and $\mathrm{CH}_{4}$ (Bange, 2006; Bastviken et al., 2011; Borges et al., 2015; Murray et al., 2015; Seitzinger and Kroeze, 1998).

In aquatic systems, $\mathrm{N}_{2} \mathrm{O}$ is mainly formed as a byproduct during nitrification $\left(\mathrm{NH}_{4}^{+} \rightarrow \mathrm{NO}_{3}^{-}\right)$and to minor extent as an intermediate during denitrification $\left(\mathrm{NO}_{3}^{-} \rightarrow \mathrm{N}_{2} \mathrm{O} \rightarrow \mathrm{N}_{2}\right.$ ) (Freing et al., 2010). In both processes, the yield of $\mathrm{N}_{2} \mathrm{O}$ strongly depends on the concentration of oxygen $\left(\mathrm{O}_{2}\right)$ (e.g., Bange, 2008). Both nitrification and denitrification are microbial processes and occur in the water column and in sediments (e.g., Bange, 2008). $\mathrm{CH}_{4}$ is formed during the decomposition of organic material by microbial methanogenesis (e.g., Reeburgh, 2007; Valentine, 2011; Ferry, 2010). Since $\mathrm{CH}_{4}$ formation requires strictly anaerobic conditions, $\mathrm{CH}_{4}$ is produced in anoxic environments found in sediments, in the interior of suspended particles or in zooplankton guts (see, e.g., Reeburgh, 2007; Valentine, 2011). Additionally, $\mathrm{CH}_{4}$ is oxidized under aerobic and anaerobic conditions in the water column and in the sediments, respectively (e.g., Valentine, 2011). On the continental shelf so-called geological $\mathrm{CH}_{4}$ can be released directly to the water column through mud volcanoes, via groundwater input or seeping at pockmark structures (e.g., Valentine, 2011). Alternative aerobic $\mathrm{CH}_{4}$ formation pathways in the nutrient poor (oligotrophic) surface ocean have been suggested (see, e.g., Karl et al., 2008; Damm et al., 2010; Zindler et al., 2013), but they are negligible in nutrient-rich (eutrophic) coastal systems.

In this study, we present first measurements of dissolved $\mathrm{N}_{2} \mathrm{O}$ and $\mathrm{CH}_{4}$ from the estuaries of the Lupar and Saribas rivers, which are located in northwestern Borneo (Sarawak, Malaysia, Southeast Asia). These measurements are complemented by dissolved $\mathrm{N}_{2} \mathrm{O}$ and $\mathrm{CH}_{4}$ measurements from a cruise on the adjacent coastal shelf of the South China Sea. The Lupar and Saribas rivers drain catchments which are covered by tropical peatlands, parts of which have been converted to oil palm plantations or other crops. This study aimed at investigating the effect of the carbon-rich peatlands on the $\mathrm{N}_{2} \mathrm{O}$ and $\mathrm{CH}_{4}$ estuarine distributions and emissions and the potential impact of estuarine eutrophication. Two intensive sampling campaigns took place during the dry and wet seasons in June 2013 and March 2014, respectively, and provide a first account of the seasonality in these systems.
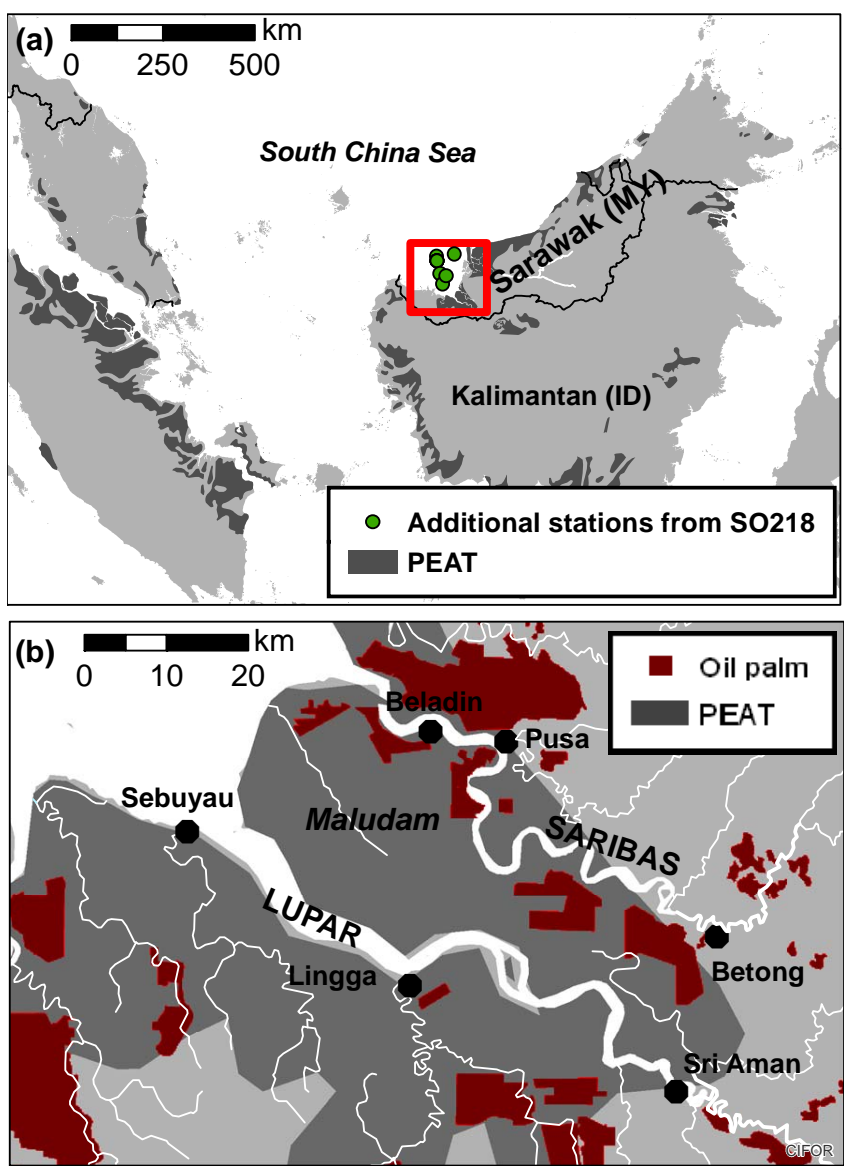

Figure 1. Map of the study area showing (a) the location of Sarawak on the island of Borneo and the cruise track of the R/V Sonne in November 2011 (SO218). (b) Close-up map of the Lupar and Saribas estuaries, enclosing the Maludam Peninsula, showing the major settlements along the rivers and estuaries. Peat areas are indicated by the dark grey area; oil palm plantations as of CIFOR (2014) are shown in red.

\section{Materials and methods}

\subsection{Study area}

Our study was conducted in Sarawak, the largest Malaysian state, which is located in the north of the island of Borneo (see Fig. 1a). About $12 \%$ of the area of Sarawak is covered by peatlands (Chai, 2005), approximately $41 \%$ of which have been converted to oil palm plantations (SarVision, 2011). Sarawak has a tropical climate with a mean annual air temperature of $26.1{ }^{\circ} \mathrm{C}$ in the capital Kuching and average (1961-1990) annual rainfall of $4101 \mathrm{~mm}$ (DWD, 2007). Between November and February, Sarawak experiences enhanced rainfall due to the Northeast Monsoon, while June and July are the driest months (DWD, 2007).

Two macrotidal estuaries which enclose Malaysia's largest peat dome, the Maludam Peninsula, are in the focus of this study. The catchment areas of the Lupar and Saribas rivers 
are 6558 and $1943 \mathrm{~km}^{2}$, respectively (Lehner et al., 2006), with approximate discharges of 490 and $160 \mathrm{~m}^{3} \mathrm{~s}^{-1}$ (Müller et al., 2016). The Lupar catchment comprises mainly the division of Sri Aman, which has a population of approximately 95 000. The Saribas basin belongs largely to the Betong division, with a population of approximately 110000 (SPU, 2012). Major settlements along the Lupar River and estuary are Sri Aman, Lingga, and Sebuyau (Fig. 1b). Important settlements along the Saribas River and estuary are Betong, Pusa, and Beladin. Oil palms are being cultivated in both catchments (Fig. 1b).

In the Lupar and Saribas estuaries, sampling took place during two campaigns in June 2013 and March 2014. Our sampling strategy is described in detail in Müller et al. (2016). In that study, we showed that precipitation during June 2013 and March 2014 did not deviate much from the historical average, so we considered the measurements in June 2013 representative of the dry season and those in March 2014 representative of the wet season. Therefore, we refer to the two campaigns as "MLD dry" (June 2013) and "MLD wet" (March 2014). Note that the peak of the monsoon season is between December and February, so the monsoon recedes in March, which is why our statements about seasonality are conservative.

We complement this data set with measurements that were performed during the cruise SO218 - SHIVA with the German research vessel (R/V) Sonne (15-29 November 2011) (Quack and Krüger, 2013). The cruise started in Singapore and went along the Sarawakian coastline to end in Manila, Philippines (see Fig. 1a). For this study, we selected those samples that were taken in the coastal ocean off northwestern Sarawak (latitude < 2.5, $110.5<$ longitude $<111.5$ ) in order to complement our data set from the Lupar and Saribas estuaries.

\subsection{Water chemistry}

In the Lupar and Saribas inner and outer estuaries, we sampled 20 stations during the dry season and 23 during the wet season. Water samples were taken from approximately $1 \mathrm{~m}$ below the water surface. Samples were taken for dissolved organic carbon (DOC), dissolved inorganic (nitrogenous) nutrients $\left(\mathrm{DIN}=\mathrm{NO}_{3}^{-}, \mathrm{NO}_{2}^{-}\right.$, and $\left.\mathrm{NH}_{4}^{+}\right)$, salinity, water temperature, and $\mathrm{O}_{2}$.

Samples for DOC were filtered (pore size: $0.45 \mu \mathrm{m}$ ) and acidified with $21 \%$ phosphoric acid until the $\mathrm{pH}$ had dropped below 2. DOC concentrations were determined by high-temperature combustion and subsequent measurement of resultant $\mathrm{CO}_{2}$ with a non-dispersive infrared detector (NDIR) (EPA method 415.1). Details are given in Müller et al. (2016).

Inorganic nutrient samples were filtered through a Whatman glass microfiber filter (pore size $0.7 \mu \mathrm{m}$ ), preserved with a mercuric chloride $\left(\mathrm{HgCl}_{2}\right)$ solution, and frozen until analysis. Concentrations of $\mathrm{NO}_{3}^{-}, \mathrm{NO}_{2}^{-}$, and $\mathrm{NH}_{4}^{+}$were deter- mined spectrophotometrically (Hansen and Koroleff, 1999) at a wavelength of $540 \mathrm{~nm}$ with a continuous flow analyzer (Alliance, Austria).

Salinity and temperature were measured with a CastAway CTD at each station during the MLD cruises. Additionally, we measured conductivity using a TetraCon 925 conductivity sensor (WTW, Germany). We converted conductivity to salinity using the equations from Bennett (1976). During SO218, salinity and temperature were measured continuously with a thermosalinograph on board.

Dissolved oxygen (DO) was measured using a Multi3420 with an FDO 925 oxygen sensor (WTW, Germany). A routine function check in water-vapor-saturated air was conducted prior to the measurements using the check and calibration vessel that was provided with the sensor.

\section{$2.3 \quad \mathrm{~N}_{2} \mathrm{O}$ and $\mathrm{CH}_{4}$ measurements}

Our setup during the MLD cruises is described in detail in Müller et al. (2016). Surface water was pumped through a Weiss equilibrator (Johnson, 1999) at a rate of approximately $20 \mathrm{~L} \mathrm{~min}^{-1}$. The headspace air was analyzed using an in situ Fourier transform infrared (FTIR) trace gas analyzer (University of Wollongong, Australia). This instrument allows for the continuous and simultaneous measurements of several trace gas species, such as $\mathrm{N}_{2} \mathrm{O}$ and $\mathrm{CH}_{4}$ as well as $\mathrm{CO}_{2}$ and CO (Müller et al., 2016), with high accuracy and precision over a wide range of concentrations (Griffith et al., 2012). Spectra were averaged over $5 \mathrm{~min}$, and dry air-mole fractions were retrieved using the software MALT5 (Griffith, 1996). The gas dry-air mole fractions were corrected for pressure, water, and temperature cross-sensitivities (Hammer et al., 2013). The $\mathrm{CO}_{2}$ and $\mathrm{CO}$ data obtained from these measurements have been reported by Müller et al. (2016). Here, we present the $\mathrm{N}_{2} \mathrm{O}$ and $\mathrm{CH}_{4}$ measurements. Calibration was achieved by measuring a suite of gravimetrically prepared gas mixtures (Deuste Steininger) ranging from 324

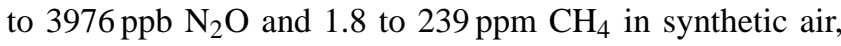
which were calibrated against the World Meteorological Organization (WMO) reference scale at the Max Planck Institute for Biogeochemistry in Jena, Germany. The error associated with the FTIR retrieval is usually small. In ambient air, the total uncertainties reported by Hammer et al. (2013) are 0.084 for $\mathrm{N}_{2} \mathrm{O}$ and $0.25 \mathrm{nmol} \mathrm{mol}^{-1}$ for $\mathrm{CH}_{4}$, corresponding to approximately 0.01 and $0.03 \%$. The larger source of uncertainty is a potentially remaining disequilibrium between water and headspace in the equilibrator, which can cause an error of $<0.2 \%$ for $\mathrm{N}_{2} \mathrm{O}$ and $2 \%$ for $\mathrm{CH}_{4}$ (Johnson, 1999).

Water temperature in the equilibrator and in the water as well as ambient air temperature and pressure were monitored as described in Müller et al. (2016). $\mathrm{N}_{2} \mathrm{O}$ and $\mathrm{CH}_{4}$ partial pressures were calculated. Since the sample air was dried before entering the FTIR analyzer, we corrected for the removal of water vapor (Dickson et al., 2007). $\mathrm{N}_{2} \mathrm{O}$ molar concentrations were calculated from $\mathrm{N}_{2} \mathrm{O}$ fugacity and solubility $\left(K_{0}\right)$ 
according to Weiss and Price (1980). $\mathrm{CH}_{4}$ molar concentrations were calculated from $\mathrm{CH}_{4}$ partial pressure, and solubilities were derived from the equations given by Wiesenburg and Guinasso (1979).

During the R/V Sonne cruise SO218, surface sea water was continuously supplied from the ship's hydrographic shaft (moon pool) using a submersible pump at about $4 \mathrm{~m}$ water depth. $\mathrm{N}_{2} \mathrm{O}$ and $\mathrm{CH}_{4}$ samples were taken in triplicates, preserved with $\mathrm{HgCl}_{2}$, and analyzed in the lab using headspace equilibration and gas chromatography. Details about the analytical procedures can be found in Walter et al. (2006) and Bange et al. (2010). The average of the three samples was calculated, and data were discarded if the standard deviation exceeded $30 \%$ of the average value. For $\mathrm{N}_{2} \mathrm{O}$, two additional data points were taken from the surface $\mathrm{N}_{2} \mathrm{O}$ concentrations determined in depth profiles.

Atmospheric mixing ratios of $\mathrm{N}_{2} \mathrm{O}$ were taken from the Mauna Loa (Hawaii) monitoring station of the NOAA/ESRL halocarbons in situ program (Dutton et al., 2015), which was the nearest atmospheric $\mathrm{N}_{2} \mathrm{O}$ monitoring station in the Northern Hemisphere. Atmospheric $\mathrm{N}_{2} \mathrm{O}$ in Mauna Loa averaged 325.15 in November 2011, 326.26 in June 2013, and $327.08 \mathrm{ppb}$ in March 2014. Atmospheric $\mathrm{CH}_{4}$ was derived from the NOAA/ESRL GMD Carbon Cycle Cooperative Global Air Sampling Network (Dlugokencky et al., 2014). The nearest atmospheric $\mathrm{CH}_{4}$ monitoring station was Bukit Kototabang, Indonesia. Unfortunately, $\mathrm{CH}_{4}$ data from NOAA/ ESRL were not available for March 2014, so we estimated the atmospheric $\mathrm{CH}_{4}$ during that month from the value reported for March 2013 and an annual growth rate of $4 \mathrm{ppb}$ between 2004 and 2013 at Bukit Kototabang. Atmospheric $\mathrm{CH}_{4}$ averaged 1841.64 in November 2011 and 1798.64 in June 2013, and a value of 1879.35 ppb was derived for March 2014.

\subsection{Flux estimation}

In order to calculate $\mathrm{N}_{2} \mathrm{O}$ and $\mathrm{CH}_{4}$ flux densities $F$ (in nmol m $\mathrm{m}^{-2} \mathrm{~s}^{-1}$ ) across the water-air interface, we used the thin-film model, which is expressed by the following equation:

$F=k K_{0}\left(p \mathrm{Gas}_{\text {water }}-p \mathrm{Gas}_{\text {air }}\right) f$,

where $k$ is the gas exchange velocity $\left(\mathrm{m} \mathrm{s}^{-1}\right), K_{\mathrm{o}}$ ist the solubility of $\mathrm{N}_{2} \mathrm{O}$ and $\mathrm{CH}_{4}$ in seawater $\left(\mathrm{molL}^{-1} \mathrm{~atm}^{-1}\right.$; see Sect. 2.3), $p \mathrm{Gas}_{\text {water }}$ is the partial pressure derived from the equilibrator measurements (natm), $p \mathrm{Gas}_{\text {air }}$ is the partial pressure of the gas in air (natm) as measured at the atmospheric monitoring stations (see Sect. 2.3), and $f$ is a conversion factor from $\mathrm{L}^{-1}$ to $\mathrm{m}^{-3}$.

For $k$, we used $k_{600}$ values that were derived for the Lupar and Saribas estuaries using the floating chamber method (Müller et al., 2016). Floating chamber measurements were conducted at several locations along the estuaries during the wet-season campaign and averaged over the spatial extent of the individual estuaries. We argued in Müller et al. (2016) that the $k_{600}$ values determined in this way are more appropriate than commonly used wind speed parameterizations, which neglect the influence of tidal currents and the water flow velocity. In situ $k$ was calculated based on the Schmidt numbers of $\mathrm{N}_{2} \mathrm{O}$ and $\mathrm{CH}_{4}$, which relates the kinematic viscosity to the diffusivity of the gas in water. Kinematic viscosity was calculated according to Siedler and Peters (1986), the diffusivity of $\mathrm{N}_{2} \mathrm{O}$ was computed using Eq. (2) in Bange et al. (2001), and the diffusivity of $\mathrm{CH}_{4}$ was calculated with the formula given in Jähne et al. (1987). The annual areal flux density was estimated as the average of the wet- and dryseason values (for the spatial extent that was covered during the 2013 cruise, see Müller et al., 2016). The total $\mathrm{N}_{2} \mathrm{O}$ and $\mathrm{CH}_{4}$ fluxes $\left(\mathrm{t} \mathrm{N} \mathrm{yr}^{-1}\right.$ and ${\mathrm{t} \mathrm{yr}^{-1}}^{-1}$ were calculated assuming an estuarine surface area of $220 \mathrm{~km}^{2}$ for the Lupar and $102 \mathrm{~km}^{2}$ for the Saribas estuary (Müller et al., 2016). For $\mathrm{N}_{2} \mathrm{O}$, we compare this estimate to one derived using the DIN export and the emission factor for estuaries suggested in Mosier et al. (1998) $(0.0025 \mathrm{~kg} \mathrm{~N} 2 \mathrm{O}-\mathrm{N} / \mathrm{kg} \mathrm{N}$ leaching and runoff). The DIN export was calculated from river discharge (see Sect. 2.1) and the median DIN concentration.

\section{Results}

\subsection{Water chemistry}

In the Lupar and Saribas estuaries, salinity ranged from 0 to 30.6 in the dry season and from 0 to 31.0 in the wet season. $\mathrm{N}_{2} \mathrm{O}$ and $\mathrm{CH}_{4}$ concentration data are available for salinities of 4.3-26.5 (MLD dry) and 6.9-26.4 (MLD wet). For the coastal ocean off northwestern Sarawak, $\mathrm{N}_{2} \mathrm{O}$ measurements covered salinities between 31.3 and 32.7 and $\mathrm{CH}_{4}$ measurements between 32.2 and 32.7. DO saturation in the estuaries ranged from 63.6 to $94.6 \%$ (MLD dry) and 79.0-100.4\% (MLD wet) (Müller et al., 2016).

The total DIN concentrations have already been published in Müller et al. (2016). Here, we report the concentrations of the different inorganic nitrogen species. Generally, DIN concentrations were quite low but locally enhanced. $\mathrm{NO}_{3}^{-}$ ranged between 6.3 and $36.3 \mu \mathrm{mol} \mathrm{L}^{-1}$ in the dry season and between 2.8 and $17.9 \mu \mathrm{mol} \mathrm{L}^{-1}$ in the wet season. A maximum value of $84.0 \mu \mathrm{mol} \mathrm{L}^{-1}$ was observed during MLD dry approximately $20 \mathrm{~km}$ offshore in the northwestern direction from Sebuyau. There, an influence from the Lupar River plume, and possibly also from the close-by Sadong River, was detected (salinity $=22.2$ ).

$\mathrm{NO}_{2}^{-}$concentrations ranged between 0.1 and $0.6 \mu \mathrm{mol} \mathrm{L}-1$ in the dry season and between $<0.1$ and $2.3 \mu \mathrm{mol} \mathrm{L}^{-1}$ in the wet season. $\mathrm{NH}_{4}^{+}$ranged between $<0.1$ and $2.6 \mu \mathrm{mol} \mathrm{L}{ }^{-1}$ in the dry season, whereas a maximum value of $8.0 \mu \mathrm{mol} \mathrm{L}^{-1}$ was observed at one station in the Lupar estuary. In the wet season, $\mathrm{NH}_{4}^{+}$was higher, ranging between 0.2 and $7.8 \mu \mathrm{mol} \mathrm{L}^{-1}$. However, overall, DIN concentrations were 

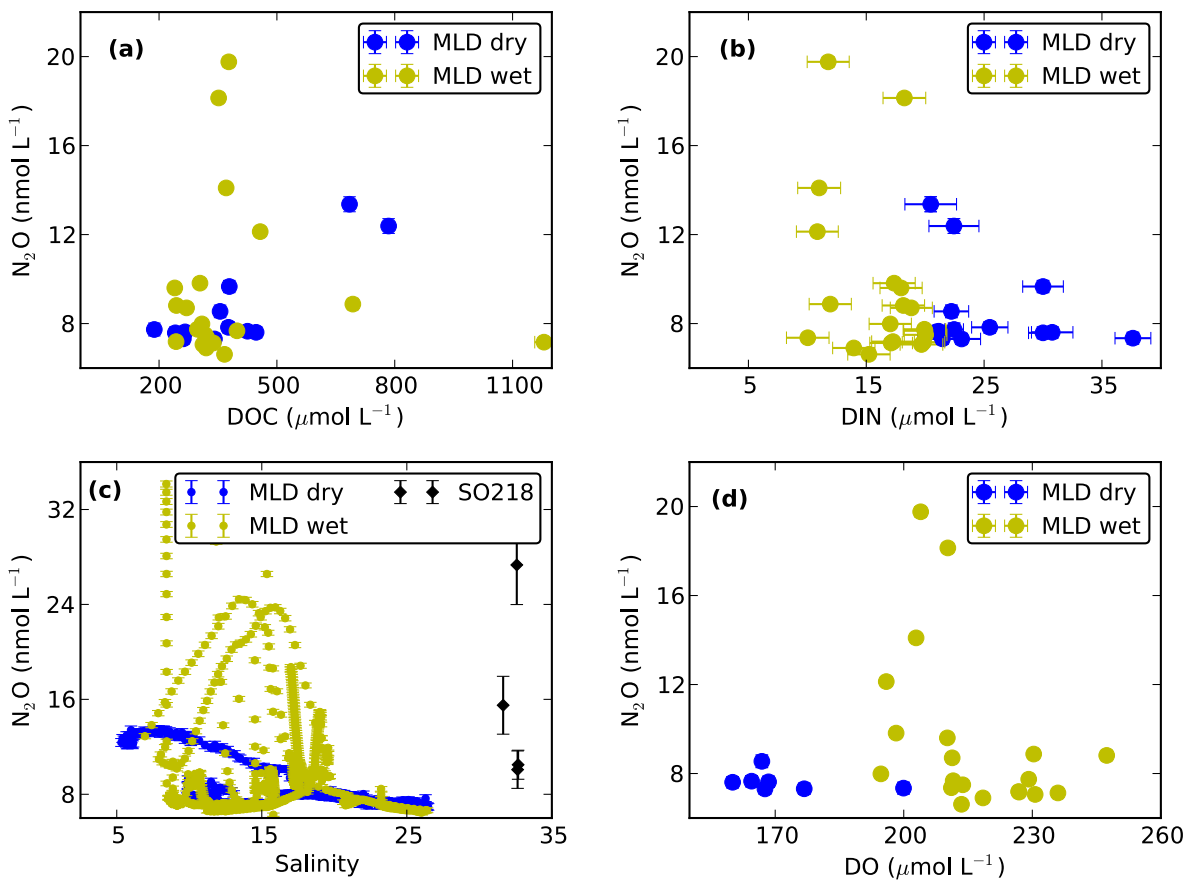

Figure 2. Relationship of nitrous oxide concentrations with (a) dissolved organic carbon (DOC), (b) dissolved inorganic nitrogen (DIN), (c) salinity, and (d) dissolved oxygen (DO). MLD refers to the campaigns on the Lupar and Saribas estuaries in the dry and wet season, respectively; SO218 denotes data from the R/V Sonne cruise.

higher in the dry season than in the wet season (Müller et al., 2016, Table 1).

On the Lupar River, we determined average DIN concentrations of 5.1 (2013) and $5.3 \mu \mathrm{mol} \mathrm{L}^{-1}$ (2014) upstream of the town of Sri Aman, which can be considered unpolluted. This value is 2-6 times lower than the DIN concentrations in the Lupar estuary. On the Saribas River, a slightly enhanced value of $18.6 \mu \mathrm{mol} \mathrm{L}^{-1}$ (2013) was measured at salinity 0 outside the town of Betong, so it cannot be considered unpolluted, yet it was lower than the DIN concentrations in the estuary during that season (Table 1). We estimated that, together, the Lupar and Saribas rivers deliver 6086t N as DIN to the South China Sea every year (Table 1).

\section{$3.2 \mathrm{~N}_{2} \mathrm{O}$}

Dissolved $\mathrm{N}_{2} \mathrm{O}$ concentrations in the water ranged from 6.9 to $13.4 \mathrm{nmol} \mathrm{L}^{-1}$ during MLD dry in June 2013 (corresponding to saturations of 103 to $184 \%$ ) and from 6.6 to $116.8 \mathrm{nmol} \mathrm{L}^{-1}$ during MLD wet in March 2014 (102 to $1679 \%$ saturation). Most of the time, $\mathrm{N}_{2} \mathrm{O}$ was close to atmospheric equilibrium. However, local enhancements were observed: during both the dry and the wet season, the Saribas tributary exhibited markedly higher $\mathrm{N}_{2} \mathrm{O}$ concentrations than the main Saribas River (Fig. 3a, b, Table 2). During the wet season, $\mathrm{N}_{2} \mathrm{O}$ concentrations were more variable (higher standard deviation, $\mathrm{SD}$ ) and higher maximum concentrations were observed (Table 2). Although the mean $\mathrm{N}_{2} \mathrm{O}$ concentra- tions in the Saribas estuary and Saribas tributary were higher in the wet season as well, no difference was found with regards to the medians (Table 2).

Salinity and $\mathrm{N}_{2} \mathrm{O}$ concentrations were correlated in the dry season $(r=-0.62)$ but uncorrelated in the wet season (Fig. 2c). By the town of Sebuyau at the Lupar River mouth, where the Sebuyau River flows into the South China Sea, $\mathrm{N}_{2} \mathrm{O}$ was enhanced with concentrations of up to $116.8 \mathrm{nmol} \mathrm{L}^{-1}$ in the wet season (not shown in Figs. 2-4). The data from $\mathrm{SO} 218$ revealed enhanced $\mathrm{N}_{2} \mathrm{O}$ concentrations offshore during November 2011 (see Fig. 2c), with a median of $13.0 \pm 7.0 \mathrm{nmol} \mathrm{L}^{-1}(218 \pm 119 \%$ saturation; see Table 2).

$\mathrm{N}_{2} \mathrm{O}$ was correlated with DOC (Fig. 2a); this correlation was strong in the dry season $(r=0.87)$ and weak during the wet season $(r=0.38)$. $\mathrm{N}_{2} \mathrm{O}$ concentrations were not correlated with DIN (Fig. 2b), $\mathrm{NO}_{3}^{-}, \mathrm{NH}_{4}^{+}$(not shown), or $\mathrm{DO}$ (Fig. 2d). During the dry season, we found no link between $\mathrm{N}_{2} \mathrm{O}$ concentrations and tidal variations (Fig. 4a). In the wet season, however, $\mathrm{N}_{2} \mathrm{O}$ exhibited slightly higher concentrations during low tide, and its spatiotemporal variation resembled that of $\mathrm{CH}_{4}$ (Fig. 4b).

\section{$3.3 \mathrm{CH}_{4}$}

Dissolved $\mathrm{CH}_{4}$ concentrations ranged from 5.2 to $59 \mathrm{nmol} \mathrm{L}^{-1}$ during MLD dry in 2013 (228 to $2782 \%$ saturation) and from 3.7 to $135 \mathrm{nmol} \mathrm{L}^{-1}$ during MLD wet 

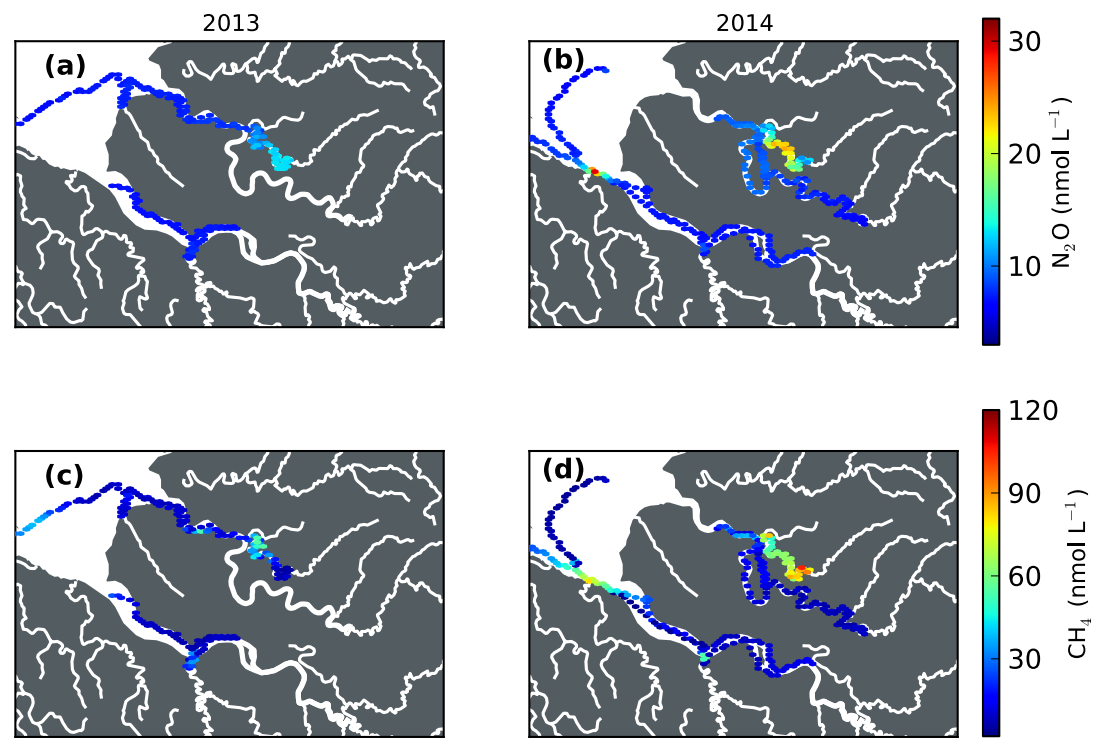

Figure 3. Dissolved $\mathrm{N}_{2} \mathrm{O}(\mathbf{a}, \mathbf{b})$ and $\mathrm{CH}_{4}(\mathbf{c}, \mathbf{d})$ concentrations measured during the 2013 (left) and 2014 (right) MLD campaigns.

Table 1. Estuarine DIN concentration medians for the spatial extent that was covered in 2013 and the estimated inorganic $\mathrm{N}$ export to the South China Sea.

\begin{tabular}{|c|c|c|c|c|c|c|c|}
\hline & \multicolumn{5}{|c|}{$\operatorname{DIN}(\mu \mathrm{mol} \mathrm{L}-1)$} & \multirow[t]{2}{*}{$\mathrm{N}$ export $\left(\mathrm{t} \mathrm{yr}^{-1}\right)$} \\
\hline & & Min & Max & Mean & Median & SD & \\
\hline Lupar & dry & 20.9 & 30.8 & 23.6 & 22.2 & 3.6 & \multirow[t]{2}{*}{4532} \\
\hline River & wet & 11.9 & 21.7 & 18.2 & 19.7 & 3.2 & \\
\hline Saribas & dry & 25.5 & 37.6 & 31.0 & 30.0 & 6.1 & \multirow[t]{2}{*}{1554} \\
\hline River & wet & 10.0 & 18.0 & 14.0 & 14.0 & 5.6 & \\
\hline Saribas & dry & 20.5 & 30.0 & 24.3 & 22.4 & 5.0 & \multirow[t]{2}{*}{ n.d. } \\
\hline tributary & wet & 10.9 & 18.2 & 13.0 & 11.4 & 3.5 & \\
\hline
\end{tabular}

in 2014 (168 to $6003 \%$ saturation) in the Lupar and Saribas estuaries and were spatially variable. The highest value was measured by the town of Sebuyau during MLD wet, whereas the highest median concentrations were detected in the Saribas estuary during the dry season and in the Saribas tributary during the wet season (Fig. 3c, d; Table 3). In general, no seasonal pattern could be identified. Mean and median $\mathrm{CH}_{4}$ concentrations in the Lupar estuary were comparable in the dry and wet seasons. In the Saribas estuary, $\mathrm{CH}_{4}$ concentrations were higher during the dry season, but in the Saribas tributary they were higher during the wet season (Table 3). However, higher maximum concentrations were observed in the wet season in both estuaries and the tributary (Table 3).

$\mathrm{CH}_{4}$ concentrations were not correlated with salinity (Fig. 5c). A relatively low marine end-member concentration was determined during the SO218 cruise: with a median of $3.6 \pm 0.2 \mathrm{nmol} \mathrm{L}^{-1}$ (176 $\pm 9 \%$ saturation), $\mathrm{CH}_{4}$ concentrations in the coastal ocean were only slightly enhanced in comparison to the atmospheric equilibrium concentration (see Table 3).

$\mathrm{CH}_{4}$ was not correlated with DOC (Fig. 5a), DO (Fig. 5d), DIN, or suspended particulate matter (not shown) but increased with increasing $p \mathrm{CO}_{2}$ (Fig. 5b). This relationship was stronger in the wet season $(r=0.55)$ than in the dry season $(r=0.15)$. One striking feature was that $\mathrm{CH}_{4}$ showed a strong response to the tides (Fig. 4). This is visible for most of the data, even though we changed location during the measurements. Tidal and spatial variations are overlapping in Fig. 4, but the tidal variation seems to dominate. This is confirmed by one stationary measurement that we conducted overnight at one station on the Saribas tributary in 2014 (Fig. 4b): $\mathrm{CH}_{4}$ during low tide peaked at 4 times the concentration during high tide.

\section{$3.4 \mathrm{~N}_{2} \mathrm{O}$ and $\mathrm{CH}_{4}$ flux densities}

Median $\mathrm{N}_{2} \mathrm{O}$ and $\mathrm{CH}_{4}$ flux densities are listed in Table 4. Both the highest $\mathrm{N}_{2} \mathrm{O}$ flux density and the highest $\mathrm{CH}_{4}$ flux 
Table 2. $\mathrm{N}_{2} \mathrm{O}$ concentrations and saturations in the Lupar River, Saribas River, Saribas tributary, and coastal ocean. Values for the estuaries are given for the spatial extent of the rivers that was covered in 2013.

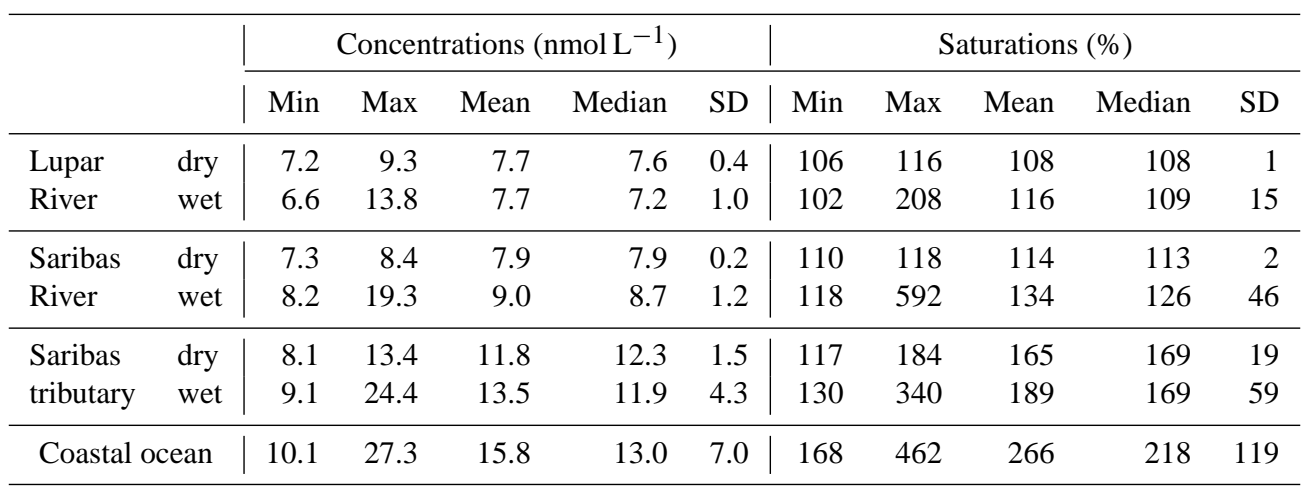
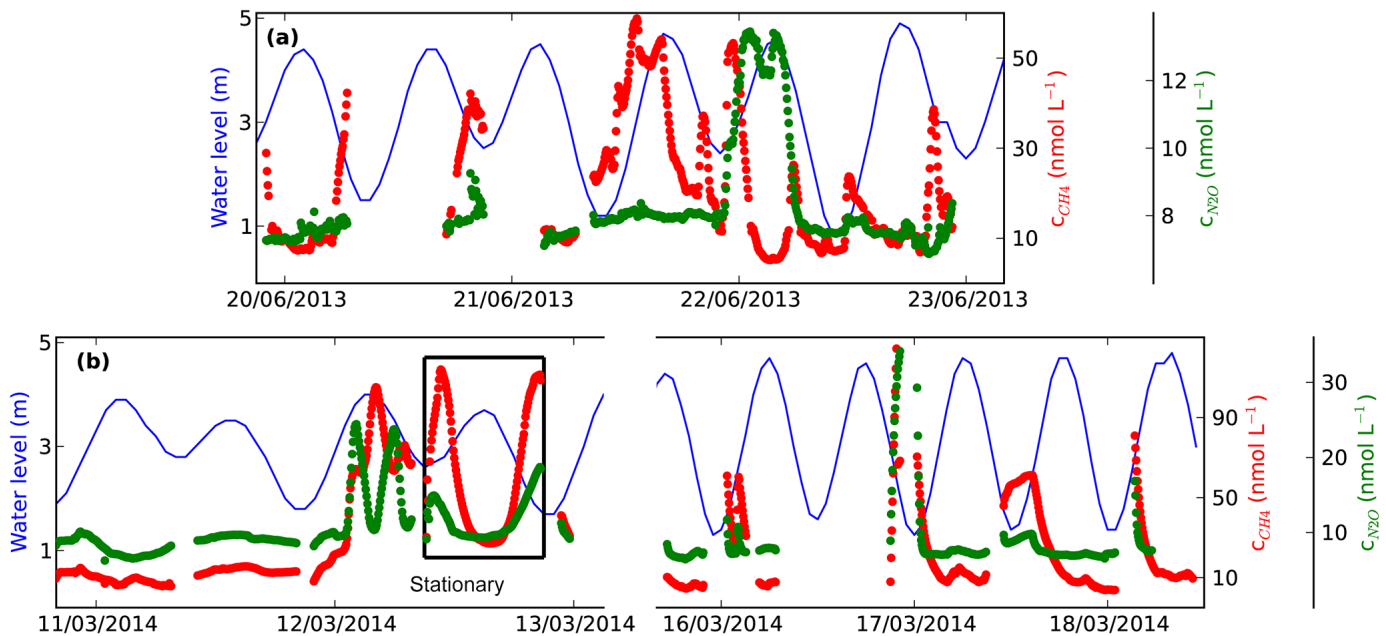

Figure 4. Time series of methane and nitrous oxide concentrations in the Lupar and Saribas estuaries measured during the dry-season (2013) campaign (upper panel) and the wet-season campaign (lower panel) and the water level as predicted for Pulau Lakei (+1 h for Lupar and Saribas rivers). Spatial, temporal and tidal variations are overlapping in the figure. One stationary measurement, as recorded on the Saribas River in 2014, is denoted with the black box. Note the discontinuous time axis in the lower panel.

density were computed for the Saribas tributary. During both seasons, $\mathrm{N}_{2} \mathrm{O}$ flux densities from the Saribas tributary were up to one order of magnitude higher than from the Lupar and the Saribas estuaries. Annual average $\mathrm{N}_{2} \mathrm{O}$ flux densities were low for both the Lupar and Saribas rivers, amounting to $1.3 \pm 0.3$ and $1.9 \pm 1.6 \mathrm{mmol} \mathrm{m}^{-2} \mathrm{yr}^{-1}$, respectively. The $\mathrm{N}_{2} \mathrm{O}$ flux density from the Saribas tributary was one order of magnitude higher $\left(12.0 \pm 7.5 \mathrm{mmol} \mathrm{m}^{-2} \mathrm{yr}^{-1}\right)$.

The $\mathrm{CH}_{4}$ flux density observed on the Saribas tributary during the wet season was approximately 5 times higher than the flux densities from the Lupar or Saribas River during any season. As a result, the annual average flux from the Saribas tributary $\left(89.2 \pm 55.2 \mathrm{mmol} \mathrm{m}^{-2} \mathrm{yr}^{-1}\right)$ was approximately 4 times as high as those computed for the Lupar and Saribas estuaries, which were comparable $(22.5 \pm 5.4$ and $23.0 \pm 19.1 \mathrm{mmol} \mathrm{m}^{-2} \mathrm{yr}^{-1}$, respectively).
In total, $4 \pm 1 \mathrm{t} \mathrm{N}_{2} \mathrm{O}-\mathrm{N} \mathrm{yr}^{-1}$ and $60 \pm 17 \mathrm{t} \mathrm{CH}_{4}-\mathrm{C} \mathrm{yr}^{-1}$ were emitted from the Lupar estuary, and $3 \pm 2 \mathrm{t} \mathrm{N}_{2} \mathrm{O}-\mathrm{N} \mathrm{yr}^{-1}$ and $28 \pm 25 \mathrm{t} \mathrm{CH}_{4}-\mathrm{C} \mathrm{yr}^{-1}$ from the Saribas (Table 4). Using the emission factor of Mosier et al. (1998), we obtained emission estimates of $11 \mathrm{t} \mathrm{N}_{2} \mathrm{O}-\mathrm{N} \mathrm{yr}^{-1}$ for the Lupar and $4 \mathrm{t}$ $\mathrm{N}_{2} \mathrm{O}-\mathrm{N} \mathrm{yr}^{-1}$ for the Saribas estuary.

\section{Discussion}

\subsection{Eutrophication in the Lupar and Saribas estuaries}

Blackwater rivers and their estuaries usually have very low nutrient concentrations $\left(<1 \mu \mathrm{mol} \mathrm{L}{ }^{-1} \mathrm{NO}_{3}^{-}\right.$, Kselik and Liong 2004 ; $<5 \mu \mathrm{mol} \mathrm{L}{ }^{-1} \mathrm{NO}_{3}^{-}$, Alkhatib et al., 2007). Although the Lupar and Saribas rivers are not blackwater rivers, they have several blackwater tributaries (Kselik and Liong 2004; Müller et al., 2016), and 30.5 and $35.5 \%$ of their catch- 
Table 3. $\mathrm{CH}_{4}$ concentrations and saturations in the Lupar River, Saribas River, Saribas tributary, and coastal ocean. Values for the estuaries are given for the spatial extent of the rivers that was covered in 2013.

\begin{tabular}{lc|rrrrr|rrrrr}
\hline & & \multicolumn{4}{|c|}{ Concentrations $\left(\mathrm{nmol} \mathrm{L}^{-1}\right)$} & \multicolumn{5}{c}{ Saturations (\%) } \\
\cline { 3 - 12 } & & Min & Max & Mean & Median & SD & Min & Max & Mean & Median & SD \\
\hline Lupar & dry & 7.3 & 42.3 & 18.7 & 10.6 & 12.2 & 339 & 1910 & 837 & 486 & 520 \\
River & wet & 3.7 & 61.2 & 24.4 & 13.5 & 20.3 & 168 & 2799 & 1104 & 615 & 915 \\
\hline Saribas & dry & 8.3 & 58.8 & 28.2 & 25.6 & 15.5 & 397 & 2782 & 1331 & 1188 & 727 \\
River & wet & 9.0 & 68.5 & 15.1 & 12.2 & 9.1 & 401 & 3050 & 671 & 545 & 395 \\
\hline $\begin{array}{l}\text { Saribas } \\
\text { tributary }\end{array}$ & dry & 5.2 & 53.3 & 20.6 & 12.4 & 16.9 & 228 & 2458 & 942 & 554 & 784 \\
\hline \multicolumn{2}{l}{ Coastal ocean } & 23.3 & 113.9 & 63.2 & 64.0 & 27.4 & 1040 & 5058 & 2773 & 2786 & 1198 \\
\hline
\end{tabular}
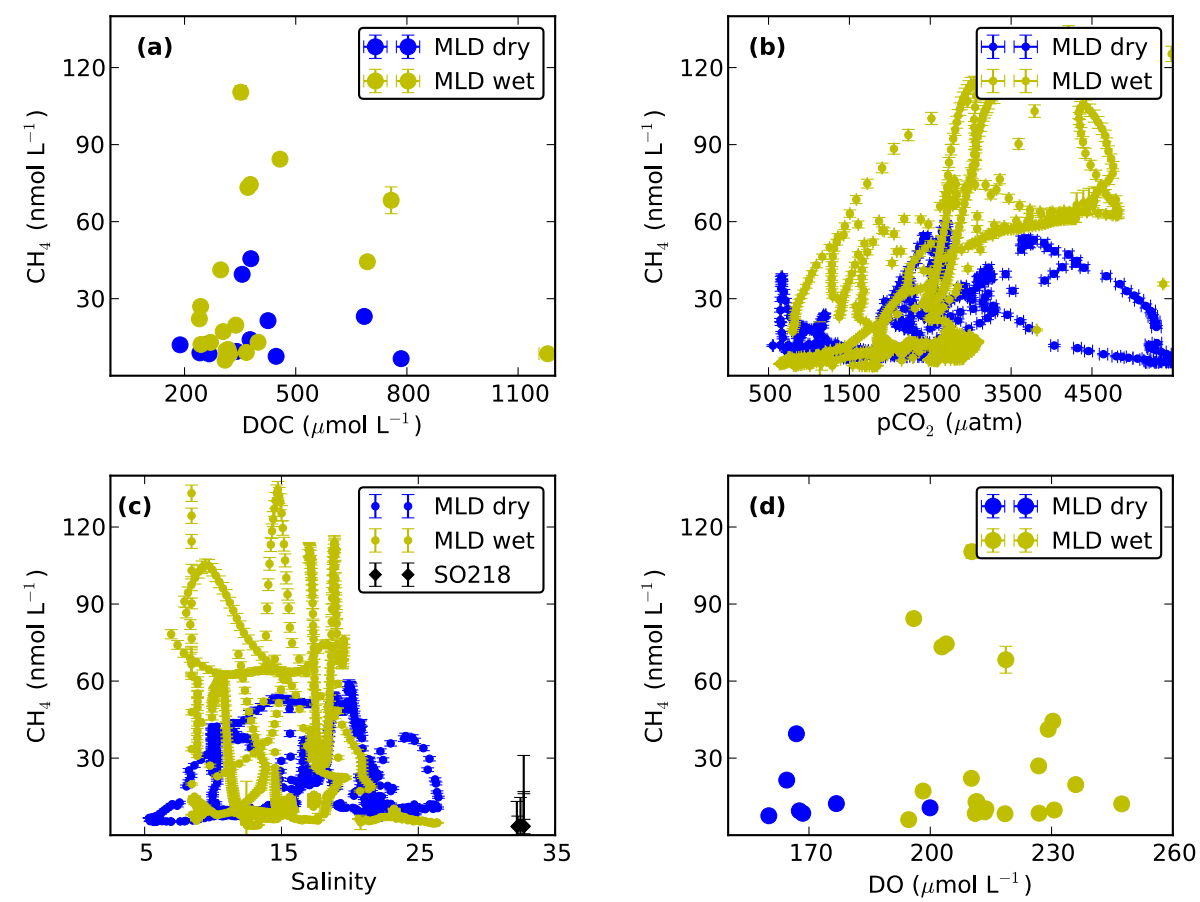

Figure 5. Relationship of methane concentrations with (a) dissolved organic carbon (DOC), (b) $p \mathrm{CO}_{2}$, (c) salinity, and (d) dissolved oxygen (DO). MLD refers to the campaigns on the Lupar and Saribas estuaries in the dry and wet season, respectively; SO218 denotes data from the $\mathrm{R} / \mathrm{V}$ Sonne cruise.

ments are covered by peat, respectively (Müller et al., 2016). Therefore, rather low nutrient concentrations were expected. However, several villages and smaller towns are found along the shore of both estuaries, and there is cultivation of sago and oil palm in the catchments (Fig. 1b).

Estuarine DIN concentrations were higher than in the unpolluted freshwater end-member of the Lupar River, indicating that the estuary was indeed slightly eutrophic during the time of our measurements. This eutrophication can be attributed both to the release of DIN during respiration of organic matter, which was shown to be pronounced in the Lupar and Saribas estuaries (Müller et al., 2016), espe- cially in the dry season (see discussion below), and to anthropogenic input. These processes were also identified as important sources of inorganic nutrients in the Siak River, a eutrophic blackwater river in central Sumatra, Indonesia (Baum and Rixen, 2014). The DIN concentrations in the Lupar and Saribas estuaries were similar to those reported by Baum and Rixen (2014) for the Siak River.

Eutrophication can lead to enhanced estuarine primary production and consequently to hypoxia. This was not observed. Although organic matter was respired in the estuaries (Müller et al., 2016), oxygen depletion was relatively moderate in the surface water due to a quick replenishment from 
the overlying air, as suggested by the high gas exchange velocity (Table 4). Since we did not measure oxygen profiles, we can only speculate about the oxygen levels in the bottom water. The high turbulence in the water likely prevented stratification and promoted the ventilation of the water column and, therefore, may have prevented the development of anoxic bottom waters.

\section{$4.2 \quad \mathrm{~N}_{2} \mathrm{O}$}

Dissolved $\mathrm{N}_{2} \mathrm{O}$ concentrations were mostly close to atmospheric equilibrium concentrations (i.e., $100 \%$ saturation), which is in line with other comparable studies in the tropics and subtropics (Richey et al., 1988; Zhang et al., 2010; Rao and Sarma 2013; Borges et al., 2015). High $\mathrm{N}_{2} \mathrm{O}$ concentrations were reported for eutrophic and hypoxic coastal waters in the western Indian continental shelf (up to $533 \mathrm{nmol} \mathrm{L}^{-1}$; Naqvi et al., 2000) and for the Peruvian upwelling (up to $986 \mathrm{nmol} \mathrm{L}^{-1}$; Arevalo-Martinez et al., 2015). Similarly, $\mathrm{N}_{2} \mathrm{O}$ concentrations in the subtropical Brisbane estuary were higher than in the Lupar and Saribas rivers (median concentrations between 7.2 and $12.3 \mathrm{nmol} \mathrm{L}^{-1}$ ), ranging between 9.1 and $45 \mathrm{nmol} \mathrm{L}^{-1}$ (Musenze et al., 2014).

The low $\mathrm{N}_{2} \mathrm{O}$ concentrations in the Lupar and Saribas estuaries are not surprising. Even though these estuaries were slightly eutrophic, the DIN concentrations were still below the average for tropical non-blackwater rivers (Baum and Rixen, 2014). For estuaries with low DIN concentrations, low $\mathrm{N}_{2} \mathrm{O}$ concentrations are expected (Zhang et al., 2010). Interestingly, enhanced $\mathrm{N}_{2} \mathrm{O}$ was measured offshore during cruise $\mathrm{SO} 218$. Either a source of $\mathrm{N}_{2} \mathrm{O}$ exists on the continental shelf or the enhanced $\mathrm{N}_{2} \mathrm{O}$ concentrations are due to interannual variability: the SO218 cruise took place in 2011, while the measurements in the Lupar and Saribas estuaries were performed in 2013 and 2014. Ultimately, the SO218 measurements were performed at the onset of the monsoon season, so seasonal variability possibly plays a role. This is considered most likely, as it is in line with the tendency towards higher and more variable $\mathrm{N}_{2} \mathrm{O}$ concentrations during MLD wet when compared to MLD dry in the Saribas tributary.

Stronger oxygen depletion and higher DIN concentrations suggest higher respiration rates during the dry season (Müller et al., 2016). In accordance with this, $\mathrm{N}_{2} \mathrm{O}$ was well correlated with DOC and salinity during the dry season, suggesting that it originated mainly from respiratory activity in the upper estuary. In this study, samples were not collected for salinities $<4$, so we cannot make this claim with certainty. However, previous studies suggest that the highest $\mathrm{N}_{2} \mathrm{O}$ concentrations are usually encountered at low salinities in the vicinity of the turbidity maximum (Robinson et al., 1998; Barnes and Owens, 1998; Zhang et al., 2010). On the other hand, $\mathrm{N}_{2} \mathrm{O}$ maximum concentrations along estuaries may also occur at intermediate salinities (de Wilde and de Bie, 2000). This seems to have been the case during our wet-season campaign, where we observed the highest $\mathrm{N}_{2} \mathrm{O}$ concentrations at salinities between 10 and 20 (Fig. 2c). $\mathrm{N}_{2} \mathrm{O}$ concentrations were not correlated with salinity during the wet season, and the correlation with DOC was weak, suggesting that additional sources of $\mathrm{N}_{2} \mathrm{O}$ existed in the estuary and obscured these relationships. The nature of this additional estuarine source is indicated by the covariation of $\mathrm{N}_{2} \mathrm{O}$ and $\mathrm{CH}_{4}$. The variability of both gases was linked to the tidal cycle, which was not the case for $\mathrm{N}_{2} \mathrm{O}$ during MLD dry (see Fig. 4). This implies that $\mathrm{N}_{2} \mathrm{O}$ and $\mathrm{CH}_{4}$ had the same source during the wet season and that this source was located within the estuary at intermediate salinities. In line with the tidal variability, we propose production of both $\mathrm{N}_{2} \mathrm{O}$ and $\mathrm{CH}_{4}$ in estuarine sediments or in tidal creeks as a common source of both gases.

The most striking feature of the spatial distribution of $\mathrm{N}_{2} \mathrm{O}$ was its strong variability, with enhanced concentrations in the Saribas tributary during both seasons, indicating a local source. The most obvious candidate for a point source is anthropogenic, i.e., sewage. However, $\mathrm{NO}_{3}^{-}, \mathrm{NO}_{2}^{-}$, and $\mathrm{NH}_{4}^{+}$ were not enhanced in the same way as $\mathrm{N}_{2} \mathrm{O}$, suggesting that DIN concentrations are a poor predictor of estuarine $\mathrm{N}_{2} \mathrm{O}$ concentrations (see discussion below).

\section{$4.3 \mathrm{CH}_{4}$}

Similar to $\mathrm{N}_{2} \mathrm{O}$, dissolved $\mathrm{CH}_{4}$ concentrations were relatively moderate. For example, while $\mathrm{CH}_{4}$ concentrations in the partially hypoxic Pearl River estuary ranged between 23 and $2984 \mathrm{nmol} \mathrm{L}^{-1}$ (Chen et al., 2008), median $\mathrm{CH}_{4}$ concentrations in our study area varied between 4 and $64 \mathrm{nmol} \mathrm{L}-1$. Similarly, the $\mathrm{CH}_{4}$ concentration range reported by Musenze et al. (2014) for the Brisbane estuary, Australia, was substantially higher $\left(31-578 \mathrm{nmol} \mathrm{L}^{-1}\right)$ than in this study, although both the DOC concentration range and the DO saturation range were similar. This is surprising, as the peat-draining tributaries are extremely oxygen-depleted and contain large amounts of organic matter (Müller et al., 2015). These conditions are usually suitable for $\mathrm{CH}_{4}$ production. Although we do not have data on the river end-member $\mathrm{CH}_{4}$ concentration, we can infer from the lack of correlation between $\mathrm{CH}_{4}$ and salinity that freshwater input was not the main source of $\mathrm{CH}_{4}$ in the estuaries. Since $\mathrm{CH}_{4}$ is a poorly soluble gas, a large fraction might be released to the atmosphere before reaching the estuary and the coastal ocean. Another possible explanation is methane oxidation, which was shown to remove large fractions of $\mathrm{CH}_{4}$ in some estuaries (de Angelis and Scranton, 1993; Abril et al., 2007). Although $\mathrm{CH}_{4}$ concentrations tended to be higher during the wet season, a clear seasonal pattern of $\mathrm{CH}_{4}$ concentrations was not apparent, which is in line with observations at other tropical (Barnes et al., 2006; Teodoru et al., 2014) and subtropical (Musenze et al., 2014) sites.

The generally positive relationship between $\mathrm{CH}_{4}$ and $p \mathrm{CO}_{2}$ has been observed in other tropical aquatic systems 
Table 4. $k_{600}$ values and median $\mathrm{N}_{2} \mathrm{O}$ and $\mathrm{CH}_{4}$ areal and total fluxes from the Lupar River, Saribas River, and Saribas tributary. The uncertainties relate to the maximum variability of the $k_{600}$ value, as the $k_{600}$ uncertainty propagation was responsible for approximately $96 \%$ of the flux uncertainty. Values are given for the spatial extent of the rivers that was covered in 2013.

\begin{tabular}{|c|c|c|c|c|c|c|c|c|}
\hline & \multirow[t]{2}{*}{$\begin{array}{l}k_{600} \\
\left(\mathrm{~cm} \mathrm{~h}^{-1}\right)\end{array}$} & \multicolumn{2}{|c|}{$\begin{array}{c}\text { Flux density } \\
\left(\text { nmol m }{ }^{-2} \mathrm{~s}^{-1}\right)\end{array}$} & \multicolumn{2}{|c|}{$\begin{array}{c}\text { Annual average flux } \\
\text { density }\left(\mathrm{mmol} \mathrm{m}^{-2} \mathrm{yr}^{-1}\right)\end{array}$} & \multicolumn{2}{|c|}{$\begin{array}{l}\text { Flux }\left(\mathrm{t} \mathrm{N} \mathrm{yr}^{-1}\right. \\
\left.\text { and } \mathrm{t} \mathrm{yr}^{-1}\right)\end{array}$} & \multirow[b]{2}{*}{$\mathrm{CH}_{4}$} \\
\hline & & & $\mathrm{N}_{2} \mathrm{O}$ & $\mathrm{CH}_{4}$ & $\mathrm{~N}_{2} \mathrm{O}$ & $\mathrm{CH}_{4}$ & $\mathrm{~N}_{2} \mathrm{O}$ & \\
\hline Lupar & dry & n.d. & $0.04 \pm 0.01$ & $0.59 \pm 0.14$ & \multirow[t]{2}{*}{$1.3 \pm 0.3$} & \multirow[t]{2}{*}{$22.5 \pm 5.4$} & \multirow[t]{2}{*}{$4 \pm 1$} & \multirow[t]{2}{*}{$60 \pm 17$} \\
\hline River & wet & $20.5 \pm 4.9$ & $0.04 \pm 0.01$ & $0.84 \pm 0.20$ & & & & \\
\hline Saribas & dry & n.d. & $0.04 \pm 0.03$ & $1.01 \pm 0.84$ & \multirow{2}{*}{$1.9 \pm 1.6$} & \multirow{2}{*}{$23.0 \pm 19.1$} & \multirow{2}{*}{$3 \pm 2$} & \multirow[t]{2}{*}{$28 \pm 25$} \\
\hline River & wet & $13.2 \pm 11.0$ & $0.08 \pm 0.07$ & $0.45 \pm 0.37$ & & & & \\
\hline \multirow[t]{2}{*}{ Saribas tributary } & dry & n.d. & $0.39 \pm 0.24$ & $0.81 \pm 0.50$ & \multirow[t]{2}{*}{$12.0 \pm 7.5$} & \multirow[t]{2}{*}{$89.2 \pm 55.2$} & \multirow[t]{2}{*}{ n.d. } & \multirow[t]{2}{*}{ n.d } \\
\hline & wet & $23.9 \pm 14.8$ & $0.37 \pm 0.23$ & $4.84 \pm 3.00$ & & & & \\
\hline
\end{tabular}

(Teodoru et al., 2014; Borges et al., 2015) and is indicative of organic matter decomposition as a source of both gases. The strong response of $\mathrm{CH}_{4}$ to tidal variations indicates that $\mathrm{CH}_{4}$ is produced in the sediments and released when the hydrostatic pressure drops during falling tide. The tidal variability of $\mathrm{CH}_{4}$ (and $\mathrm{N}_{2} \mathrm{O}$ in the wet season) can also be interpreted as an indication of the contribution of intertidal sediments and tidal creeks to the $\mathrm{CH}_{4}$ concentrations in these estuaries. The importance of tidal creeks (Middelburg et al., 2002) and tidal pumping (Barnes et al., 2006; Borges and Abril, 2011) for $\mathrm{CH}_{4}$ concentrations in estuaries is widely recognized.

\section{4 $\mathrm{N}_{2} \mathrm{O}$ and $\mathrm{CH}_{4}$ flux densities and emissions}

With the exception of the Saribas tributary $\left(F_{\text {annual }}=12.0 \pm 7.5 \mathrm{mmol} \mathrm{m}^{-2} \mathrm{yr}^{-1}\right), \quad \mathrm{N}_{2} \mathrm{O}$ flux densities were quite low $\left(1.3-1.9 \mathrm{mmol} \mathrm{m}^{-2} \mathrm{yr}^{-1}\right)$ and at the lower end of the range reported for Indian estuaries $(-0.4-$ $5.2 \mathrm{mmol} \mathrm{m}^{-2} \mathrm{yr}^{-1}$, Rao and Sarma, 2013). $\mathrm{CH}_{4}$ flux densities (22.5-89.2 $\mathrm{mmol} \mathrm{m}^{-2} \mathrm{yr}^{-1}$ ) were within the ranges reported for other tropical sites: Koné et al. (2010), for example, determined flux densities of 28.5-123.4 $\mathrm{mmol} \mathrm{m}^{-2} \mathrm{yr}^{-1}$ for stratified lagoons of Côte d'Ivoire; Shalini et al. (2006) report flux densities of $19.7-102.2 \mathrm{mmol} \mathrm{m}^{-2} \mathrm{yr}^{-1}$ for Pulicat Lake, India; and Biswas et al. (2007) measured $\mathrm{CH}_{4}$ flux densities between 0.7 and $49 \mathrm{mmol} \mathrm{m}^{-2} \mathrm{yr}^{-1}$ in the estuaries of the Sundarban mangrove ecosystem. However, we caution that the comparison suffers from the different approaches to determining the gas exchange velocity $k$. Koné et al. (2010), Shalini et al. (2006), Biswas et al. (2007), and Rao and Sarma (2013) used empirical equations relating $k$ to wind speed, while we used estimates based on floating chamber measurements. We refer to our discussion in Müller et al. (2016), where we showed that our estimates derived by floating chamber measurements yielded higher values than if we had used empirical relationships with wind speed. We argued that floating chamber measurements offered a better representation of the actual flux than gas exchange models that rely on empirical relationships with wind speed, which were initially derived for the open ocean (Wanninkhof, 1992) and do not consider current-induced turbulence as a driver of gas exchange. Musenze et al. (2014) used empirical models for both the wind-related and the current-related gas exchange velocity and added them up to derive flux estimates for the Brisbane estuary. Not surprisingly, the fluxes they report were much higher than in the aforementioned studies, with $0.8-28.0 \mathrm{mmol} \mathrm{N}_{2} \mathrm{O} \mathrm{m}^{-2} \mathrm{yr}^{-1}$ and 7.5 to $636 \mathrm{mmol}$ $\mathrm{CH}_{4} \mathrm{~m}^{-2} \mathrm{yr}^{-1}$. Compared with these estimates, the $\mathrm{N}_{2} \mathrm{O}$ and $\mathrm{CH}_{4}$ fluxes from the Lupar and Saribas rivers are quite low, which is consistent with the lower $\mathrm{N}_{2} \mathrm{O}$ and $\mathrm{CH}_{4}$ concentrations as discussed above.

On the basis of our floating chamber measurements (see Müller et al., 2016) we computed an overall annual flux of $7 \mathrm{t}$ $\mathrm{N}_{2} \mathrm{O}-\mathrm{N}$ for the Lupar and Saribas estuaries. This is only half of the estimate $\left(15 \mathrm{t} \mathrm{N}_{2} \mathrm{O}-\mathrm{N} \mathrm{yr}^{-1}\right.$ ) computed using the Mosier et al. (1998) emission factor. The reason is obviously the missing relationship between DIN concentrations and $\mathrm{N}_{2} \mathrm{O}$ emissions in the studied system. Although across estuaries increasing DIN is generally associated with increasing $\mathrm{N}_{2} \mathrm{O}$ (Murray et al., 2015), the relationship is not linear: Zhang et al. (2010) found a polynomial relationship between DIN and $\mathrm{N}_{2} \mathrm{O}$ across estuaries in different geographic locations. The emission factor from Mosier et al. (1998), in contrast, is based on a constant $\mathrm{N}_{2} \mathrm{O} / \mathrm{DIN}$ ratio. Therefore, it is not surprising that for low DIN environments, as our study site, the use of emission factors leads to a considerable bias. In line with the data presented here, Borges et al. (2015) did not find a relationship between $\mathrm{N}_{2} \mathrm{O}$ and DIN from measurements in several tropical and sub-tropical African rivers and estuaries. This could indicate that this relationship is not applicable in tropical systems and demonstrates the need for further studies in low latitudes to improve estimates of global $\mathrm{N}_{2} \mathrm{O}$ emissions from estuaries. 


\subsection{Implications for future land use change}

Nutrient loads to estuaries are predicted to increase in the future in most of Southeast Asia (Seitzinger and Kroeze, 1998). Our results imply that eutrophication in peat-dominated estuaries does not automatically lead to enhanced $\mathrm{N}_{2} \mathrm{O}$ emissions. However, the localized elevation of $\mathrm{N}_{2} \mathrm{O}$ concentrations, as observed on the Saribas tributary, suggests that estuarine $\mathrm{N}_{2} \mathrm{O}$ concentrations might be impacted by local anthropogenic sources. Indeed, it has been shown that $\mathrm{N}_{2} \mathrm{O}$ emissions from peat soils depend on land use and that cultivated sites generally exhibit higher $\mathrm{N}_{2} \mathrm{O}$ fluxes to the atmosphere (Hadi et al., 2000). It is likely that this behavior is mirrored in the aquatic systems as well.

As $\mathrm{CH}_{4}$ emissions from peatlands depend largely on the water table (Couwenberg et al., 2010), $\mathrm{CH}_{4}$ fluxes from peatlands are enhanced under sago (Melling et al., 2005) and rice (Couwenberg et al., 2010) and reduced under oil palm (Melling et al., 2005). The cultivation of sago in the catchment of the Saribas tributary might therefore partially explain the observed high $\mathrm{CH}_{4}$ fluxes from the Saribas tributary. The future development of $\mathrm{CH}_{4}$ dynamics in estuaries in this region in conjunction with land use change is hard to predict, as there are potentially counteracting effects of the conversion of peatlands to oil palm and other industrial crops, which require different agricultural practices (flooding versus drainage).

\section{Conclusions}

Overall, we found that the two tropical estuaries of the Lupar and Saribas rivers in a peat-dominated region in Malaysia were small to moderate sources of $\mathrm{N}_{2} \mathrm{O}$ and $\mathrm{CH}_{4}$ to the atmosphere. DIN concentrations were slightly enhanced compared to the unpolluted riverine end-member. This eutrophication did not lead to hypoxia or to enhanced $\mathrm{N}_{2} \mathrm{O}$ concentrations. DIN was generally a poor predictor of $\mathrm{N}_{2} \mathrm{O}$, which provides further evidence that the use of emission factors for the calculation of $\mathrm{N}_{2} \mathrm{O}$ fluxes from tropical estuaries is inappropriate. Although predictions about the future development of the Southeast Asian monsoon are highly uncertain and locally variable, it is likely that rainfall will moderately increase in this region (Christensen et al., 2013). Our results suggest that this may increase the $\mathrm{N}_{2} \mathrm{O}$ and probably also the $\mathrm{CH}_{4}$ emissions from estuaries, as the concentrations of both gases were more variable during the wet season, with higher maximum concentrations of both gases and additional sources of $\mathrm{N}_{2} \mathrm{O}$ in the estuaries. For our study area, additional sampling at the peak of the monsoon season would be desirable in order to consolidate these statements. Yet, our results provide a first account of the seasonality in these systems and underline the fact that time series measurements (seasonal sampling) are vital for the understanding of $\mathrm{N}_{2} \mathrm{O}$ and $\mathrm{CH}_{4}$ fluxes from aquatic systems in monsoonal regions.

\section{Data availability}

For measurements of dissolved $\mathrm{N}_{2} \mathrm{O}$ and $\mathrm{CH}_{4}$ in the Lupar and Saribas estuaries, our research permit entails the provision that the Sarawak Biodiversity Center (SBC) approves of intended publications prior to submission. As this cannot be guaranteed if the data can be publicly accessed, the research permit does not include permission to make data publicly available. Data are stored at the Institute of Environmental Physics, University of Bremen, Bremen, Germany, and can be requested from the corresponding author.

Measurements of dissolved $\mathrm{N}_{2} \mathrm{O}$ and $\mathrm{CH}_{4}$ during SO218 are available from the GEOMAR Helmholtz Centre for Ocean Research Kiel (https://memento.geomar. de/). Atmospheric $\mathrm{N}_{2} \mathrm{O}$ concentrations at Mauna Loa are available from the NOAA/ESRL Global Monitoring Division (ftp://aftp.cmdl.noaa.gov/data/hats/n2o/insituGCs/ CATS/monthly/). Atmospheric $\mathrm{CH}_{4}$ concentrations at Bukit Kototabang, Indonesia, are available from the NOAA/ESRL Global Monitoring Division (ftp://aftp.cmdl.noaa.gov/data/ trace_gases/ch4/flask/surface/).

Acknowledgements. We would like to thank the Sarawak Biodiversity Center for permission to conduct research in Sarawak waters (permit no. SBC-RA-0097-MM and export permit SBCEP-0040-MM). We thank Hella van Asperen (University of Bremen, Germany), Nastassia Denis, Felicity Kuek, Joanne Yeo, Hong Chang Lim, Edwin Sia (all Swinburne University, Malaysia), and all scientists and students from Swinburne University and the University of Malaysia Sarawak who were involved in the MLD cruises and their preparation. Lukas Chin and the crew members of the SeaWonder are acknowledged for their support. We thank Franziska Wittke (GEOMAR), who performed the sampling for $\mathrm{N}_{2} \mathrm{O}$ and $\mathrm{CH}_{4}$ on the R/V Sonne cruise SO218, and Annette Kock (GEOMAR), who computed the data from SO218. The authors thank Matthias Birkicht and Dorothee Dasbach (ZMT Bremen, Germany) for their help in the lab performing the analyses of the MLD samples. We acknowledge the University of Bremen for funding the MLD cruises through the "exploratory project" in the framework of the University's Institutional Strategy and the EU FP7 project InGOS for supporting the development of the FTIR measurements. Cruise SO218 was supported by the EU FP7 project SHIVA under grant agreement no. 226224.

The article processing charges for this open-access publication were covered by the University of Bremen.

Edited by: S. W. A. Naqvi

\section{References}

Abril, G., Commarieu, M. V., and Guérin, F.: Enhanced methane oxidation in an estuarine turbidity maximum, Limnol. Oceanogr., 52, 470-475, 2007. 
Alkhatib, M., Jennerjahn, T. C., and Samiaji, J.: Biogeochemistry of the Dumai River estuary, Sumatra, Indonesia, a tropical blackwater river, Limnol. Oceanogr., 52, 2410-2417, 2007.

Arévalo-Martínez, D. L., Kock, A., Löscher, C. A., Schmitz, R. A., and Bange, H. W.: Massive nitrous oxide emissions from the tropical South Pacific Ocean, Nat. Geosci., 8, 530-533, 2015.

Bange, H. W.: Nitrous oxide and methane in European coastal waters, Estuar. Coast. Shelf S., 70, 361-374, 2006.

Bange, H. W.: Gaseous nitrogen compounds ( $\mathrm{NO}, \mathrm{N}_{2} \mathrm{O}, \mathrm{N}_{2}, \mathrm{NH}_{3}$ ) in the ocean, in: Nitrogen in the Marine Environment, edited by: Capone, D. G., Bronk, D. A., Mulholland, M. R., and Carpenter, E. J., 2nd Edn., Elsevier B.V., Amsterdam, 2, 51-94, 2008.

Bange, H. W., Andreae, M. O., Lal, S., Law, C. S., Naqvi, S. W. A., Oatra, P. K., Rixen, T., and Upstill-Goddard, R. C.: Nitrous oxide emissions from the Arabian Sea: A synthesis, Atmos. Chem. Phys., 1, 61-71, doi:10.5194/acp-1-61-2001, 2001.

Bange, H. W., Bergmann, K., Hansen, H. P., Kock, A., Koppe, R., Malien, F., and Ostrau, C.: Dissolved methane during hypoxic events at the Boknis Eck time series station (Eckernförde Bay, SW Baltic Sea), Biogeosciences, 7, 1279-1284, doi:10.5194/bg7-1279-2010, 2010.

Barnes, J. and Owens, N. J. P.: Denitrification and Nitrous Oxide Concentrations in the Humber Estuary, UK, and Adjacent Coastal Zones, Mar. Pollut. Bull., 37, 247-260, 1998.

Barnes, J., Ramesh, R., Purvaja, R., Nirmal Rajkumar, A., Senthil Kumar, B., Krithika, K., Ravichandran, K., Uher, G., and UpstillGoddard, R.: Tidal dynamics and rainfall control $\mathrm{N}_{2} \mathrm{O}$ and $\mathrm{CH}_{4}$ emissions from a pristine mangrove creek, Geophys. Res. Lett., 33, L15405, doi:10.1029/2006GL026829, 2006.

Bastviken, D., Tranvik, L. J., Downing, J. A., Crill, P. M., and Enrich-Prast, A.: Freshwater methane emissions offset continental carbon sink, Science, 331, p. 50, doi:10.1126/science.1196808, 2011.

Baum, A. and Rixen, T.: Dissolved inorganic nitrogen and phosphate in the human affected blackwater river Siak, central Sumatra, Indonesia, Asian Journal of Water, Environ. Pollut., 11, 1324, 2014.

Bennett, A. S.: Conversion of in situ measurements of conductivity to salinity, Deep-Sea Res., 23, 157-165, 1976.

Biswas, H., Mukhopadhyay, S. K., Sen, S., and Jana, T. K.: Spatial and temporal patterns of methane dynamics in the tropical mangrove dominated estuary, NE coast of Bay of Bengal, India, J. Marine Syst., 68, 55-64, 2007.

Borges, A. V. and Abril, G.: Carbon dioxide and methane dynamics in estuaries, in: Treatise on Estuarine and Coastal Science, edited by: Wolanski, E. and McLusky, D. S., Academic Press, Waltham, 5, 119-161, 2011.

Borges, A. V., Darchambeau, F., Teodoru, C. R., Marwick, T. R., Tamooh, F., Geeraert, N., Omengo, F. O., Guérin, F., Lambert, T., Morana, C., Okuku, E., and Bouillon, S.: Globally significant greenhouse-gas emissions from African inland waters, Nat. Geosci., 8, 673-642, 2015.

Chai, P. K.: Management plan for Maludam National Park Betong Division Sarawak, Tech. Rep., Alterra/Forest Department Sarawak/Sarawak Forestry Corporation, Wageningen, 2005.

Chen, C. T. A., Wang, S. L., Lu, X. X., Zhang, S. R., Lui, H. K., Tseng, H. C., Wang, B. J., and Huang, H. I.: Hydrogeochemistry and greenhouse gases of the Pearl River, its estuary and beyond, Quat. Int., 186, 79-90, 2008.
Christensen, J. H., Krishna Kumar, K., Aldrian, E., An, S. I., Cavalcanti, I. F. A., de Castro, M., Dong, W., Goswami, P., Hall, A., Kanyanga, J. K., Kitoh, A., Kossin, J., Lau, N. C., Renwick, J., Stephenson, D. B., Xie, S. P., and Zhou, T.: Climate Phenomena and their Relevance for Future Regional Climate Change, in: Climate Change 2013: The Physical Science Basis. Contribution of Working Group I to the Fifth Assessment Report of the Intergovernmental Panel on Climate Change, edited by: Stocker, T. F., Qin, D., Plattner, G. K., Tignor, M., Allen, S. K., Boschung, J., Nauels, A., Xia, Y., Bex, V., and Midgley, P. M., Cambridge University Press, Cambridge, United Kingdom and New York, NY, USA, 2013.

Ciais, P., Sabine, C., Bala, G., Bopp, L., Brovkin, V., Canadell, J., Chhabra, A., DeFries, R., Galloway, J., Heimann, M., Jones, C., Le Quéré, C., Myneni, R. B., Piao, S., and Thornton, P.: Carbon and Other Biogeochemical Cycles, in: Climate Change 2013: The Physical Science Basis, Contribution of Working Group I to the Fifth Assessment Report of the Intergovernmental Panel on Climate Change, edited by: Stocker, T. F., Qin, D., Plattner, G. K., Tignor, M., Allen, S. K., Boschung, J., Nauels, A., Xia, Y., Bex, V., and Midgley, P. M., Cambridge University Press, Cambridge, United Kingdom and New York, NY, USA, 2013.

CIFOR: Center for International Forestry Research, Industrial plantations in Borneo, Shapefiles for ArcGIS, available at: http: //www.cifor.org/ (last access: 17 June 2015), 2014.

Couwenberg, J., Dommain, R., and Joosten, H.: Greenhouse gas fluxes from tropical peatlands in south-east Asia, Glob. Change Biol., 16, 1715-1732, 2010.

Damm, E., Helmke, E., Thoms, S., Schauer, U., Nöthig, E., Bakker, K., and Kiene, R. P.: Methane production in aerobic oligotrophic surface water in the central Arctic Ocean, Biogeosciences, 7, 1099-1108, doi:10.5194/bg-7-1099-2010, 2010.

de Angelis, M. A. and Scranton, M. I.: Fate of methane in the Hudson River and Estuary, Global Biogeochem. Cy., 7, 509-523, 1993.

de Wilde, H. P. J. and de Bie, M. J. M.: Nitrous oxide in the Schelde estuary: production by nitrification and emission to the atmosphere, Mar. Chem., 69, 203-216, 2000.

Dickson, A., Sabine, C., and Christian, G.: Guide to best practices for ocean $\mathrm{CO}_{2}$ measurements, North Pacific Marine Science Organization (PICES) Special Publication, 3rd Edn., available at: http://cdiac.ornl.gov/oceans/Handbook_2007.html (last access: 6 July 2015), 191 pp., 2007.

Dlugokencky, E. J., Lang, P. M., Crotwell, A. M., Masarie, K. A., and Crotwell, M. J.: Atmospheric Methane Dry Air Mole Fractions from the NOAA ESRL Carbon Cycle Cooperative Global Air Sampling Network, 1983-2013, Version: 2014-06-24, ftp: //aftp.cmdl.noaa.gov/data/trace_gases/ch4/flask/surface/ (last access: 25 April 2016), 2014.

Dutton, G. S., Elkins, J. W., and Hall, B. D.: Nitrous oxide data from the NOAA/ESRL halocarbons in situ program, available at: ftp://aftp.cmdl.noaa.gov/data/hats/n2o/insituGCs/CATS/ monthly/, (last access: 25 April 2016), 2015.

DWD: Deutscher Wetterdienst, Climate data worldwide, as Excel file, http://www.dwd.de/bvbw/appmanager/bvbw/ (last access: 3 June 2015), 2007.

Ferry, J. G.: How to make a living by exhaling methane, An. Rev. Microbiol., 64, 453-473, 2010. 
Freing, A., Wallace, D. W. R., and Bange, H. W.: Global oceanic production of nitrous oxide, Philos. Tr. R. Soc., 367, 1245-1255, 2012.

Griffith, D. W. T.: Synthetic calibration and quantitative analysis of gas-phase FT-IR spectra, Appl. Spectrosc., 50, 59-70, 1996.

Griffith, D. W. T., Deutscher, N. M., Caldow, C., Kettlewell, G., Riggenbach, M., and Hammer, S.: A Fourier transform infrared trace gas and isotope analyser for atmospheric applications, Atmos. Meas. Tech., 5, 2481-2498, doi:10.5194/amt-5-2481-2012, 2012.

Hadi, A., Inubushi, K., Purnomo, E., Razie, F., Yamakawa, K., and Tsuruta, H.: Effect of land-use changes on nitrous oxide $\left(\mathrm{N}_{2} \mathrm{O}\right)$ emission from tropical peatlands, Chemosphere, 2, 347$358,2000$.

Hammer, S., Griffith, D. W. T., Konrad, G., Vardag, S., Caldow, C., and Levin, I.: Assessment of a multi-species in situ FTIR for precise atmospheric greenhouse gas observations, Atmos. Meas. Tech., 6, 1153-1170, doi:10.5194/amt-6-1153-2013, 2013.

Hansen, H. P. and Koroleff, F.: Determination of nutrients, in: Methods of Seawater Analysis, edited by: Grasshoff, K., Kremling, K., and Ehrhardt, M., 3rd Edn., Wiley-VCH, Weinheim, 1999.

Jähne, B., Heinz, G., and Dietrich, W.: Measurement of the diffusion coefficients of sparingly soluble gases in water, J. Geophys. Res., 92, 10767-10776, 1987.

Johnson, J. E.: Evaluation of a seawater equilibrator for shipboard analysis of dissolved oceanic trace gases, Anal. Chim. Acta, 395, 119-132, 1999.

Karl, D. M., Beversdorf, L., Björkman, K. M., Church, M. J., Martinez, A., and Delong, E. F.: Aerobic production of methane in the sea, Nat. Geosci., 1, 473-478, 2008.

Koné, Y. J. M., Abril, G., Delille, B., and Borges, A. V.: Seasonal variability of methane in the rivers and lagoons of Ivory Coast (West Africa), Biogeochemistry, 100, 21-37, 2010.

Kselik, R. A. L. and Liong, T. Y.: Hydrology of the peat swamp in the Maludam National Park Betong Division Sarawak, Tech. Rep., Alterra/Forest Department Sarawak/Sarawak Forestry Corporation, Kuching, Sarawak, Malaysia, 2004.

Lehner, B., Verdin, K., and Jarvis, A.: HydroSHEDS technical documentation. World Wildlife Funds US, Washington, DC, 1st Edn., http://hydrosheds.cr.usgs.gov (last access: 17 June 2015), 2006.

Melling, L., Hatano, R., and Goh, K. J.: Methane Fluxes from three ecosystems in tropical peatland of Sarawak, Malaysia, Soil Biol. Biogeochem., 37, 1445-1453, 2005.

Middelburg, J. J., Nieuwenhuize, J., Iversen, N., Hogh, N., de Wilde, H., Helder, W., Seifert, R., and Christof, O.: Methane distribution in European tidal estuaries, Biogeochemistry, 59, 95$119,2002$.

Mosier, A., Kroeze, C., Nevison, C., Oenema, O., Seitzinger, S. P., and van Cleemput, O.: Closing the global $\mathrm{N}_{2} \mathrm{O}$ budget: nitrous oxide emissions through the agricultural nitrogen cycle, Nutr. Cycl. Agroecosys., 52, 225-248, 1998.

Müller, D., Warneke, T., Rixen, T., Müller, M., Jamahari, S., Denis, N., Mujahid, A., and Notholt, J.: Lateral carbon fluxes and $\mathrm{CO}_{2}$ outgassing from a tropical peat-draining river, Biogeosciences, 12, 5967-5979, doi:10.5194/bg-12-5967-2015, 2015.

Müller, D., Warneke, T., Rixen, T., Müller, M., Mujahid, A., Bange, H. W., and Notholt, J.: Fate of terrestrial organic carbon and associated $\mathrm{CO}_{2}$ and $\mathrm{CO}$ emissions from two Southeast Asian estuar- ies, Biogeosciences, 13, 691-705, doi:10.5194/bg-13-691-2016, 2016.

Murray, R. H., Erler, D. V., and Eyre, B. D.: Nitrous oxide fluxes in estuarine environments: response to global change, Glob. Change Biol., 21, 3219-3245, doi:10.1111/gcb.12923, 2015.

Musenze, R. S., Werner, U., Grinham, A., Udy, J., and Yuan, Z.: Methane and nitrous oxide emissions from a subtropical estuary (the Brisbane River estuary, Australia), Sci. Total Environ., 472, 719-729, 2014.

Myhre, G., Shindell, D., Bréon, F. M., Collins, W., Fuglestvedt, J., Huang, J., Koch, D., Lamarque, J. F., Lee, D., Mendoza, B., Nakajima, T., Robock, A., Stephens, G., Takemura, T., and Zhang, H.: Anthropogenic and natural radiative forcing, in: Climate Change 2013: The Physical Science Basis, Contribution of Working Group I to the Fifth Assessment Report of the Intergovernmental Panel on Climate Change, edited by: Stocker, T., Qin, D., Plattner, G. K., Tignor, M., Allen, S., Boschung, J., Nauels, A., Xia, Y., Bex, V., and Midgley, P., Cambridge University Press, Cambridge, United Kingdom and New York, 2013.

Naqvi, S. W. A., Jayakumar, D. A., Narvekar, P. V., Naik, H., Sarma, V. V. S. S., D’Souza, W., Joseph, S., and George, M. D.: Increased marine production of $\mathrm{N}_{2} \mathrm{O}$ due to intensifying anoxia on the Indian continental shelf, Nature, 408, 346-349, 2000.

Quack, B. and Krüger, K.: Stratospheric ozone: Halogen Impacts in a Varying Atmosphere, GEOMAR-Report 12, ISSN 2193-8113, 2013.

Rao, G. D. and Sarma, V. V. S. S.: Contribution of $\mathrm{N}_{2} \mathrm{O}$ emissions to the atmosphere from Indian monsoonal estuaries, Tellus B, 65, 19660, doi:10.3402/tellusb.v65i0.19660, 2013.

Reeburgh, W. S. Oceanic methane biogeochemistry, Chem. Rev., 107, 486-513, 2007.

Richey, J. E., Devol, A. H., Wofsy, S. C., Victoria, R., and Riberio, M. N. G.: Biogenic gases and the oxidation and reduction of carbon in Amazon River and floodplain waters, Limnol. Oceanogr., 33, 551-561, 1988.

Robinson, A. D., Nedwell, D. B., Harrison, R. M., and Ogilvie, B. G.: Hypernutrified estuaries as sources of $\mathrm{N}_{2} \mathrm{O}$ emission to the atmosphere: the estuary of the River Colne, Essex, UK, Mar. Ecol. Prog. Ser., 164, 59-71, 1998.

SarVision: Impact of oil palm plantations on peatland conversion in Sarawak 2005-2010, Tech. Rep., SarVision, Wageningen, 2011.

Seitzinger, S. P. and Kroeze, C.: Global distribution of nitrous oxide production and $\mathrm{N}$ inputs in freshwater and coastal marine ecosystems, Global Biogeochem. Cy., 12, 93-113, 1998.

Shalini, A., Ramesh, R., Purvaja, R., and Barnes, J.: Spatial and temporal distribution of methane in an extensive shallow estuary, south India, J. Earth Syst. Sci., 115, 451-460, 2006.

Siedler, G. and Peters, H.: Properties of sea water, in: Oceanography, edited by: Sündermann, J., Landolt-Börnstein, vol. 3a, Springer Verlag, New York, 233-264, 1986.

SPU: State Planning Unit Sarawak Facts and Figures 2012, available at: http://www.spu.sarawak.gov.my/download_facts. html (last access: 23 June 2015), 2012.

Teodoru, C. R., Nyoni, F. C., Borges, A. V., Darchambeau, F., Nyambe, I., and Bouillon, S.: Dynamics of greenhouse gases $\left(\mathrm{CO}_{2}, \mathrm{CH}_{4}, \mathrm{~N}_{2} \mathrm{O}\right)$ along the Zambezi River and major tributaries, and their importance in the riverine carbon budget, Biogeosciences 12, 2431-2453, doi:10.5194/bg-12-2431-2015, 2014. 
Valentine, D. L.: Emerging topics in marine methane biogeochemistry, Ann. Rev. Mar. Sci., 3, 147-171, 2011.

Walter, S., Bange, H. W., Breitenbach, U., and Wallace, D. W. R.: Nitrous oxide in the north atlantic ocean, Biogeosciences, 3, 607-619, 2006.

Wanninkhof, R.: Relationship between wind speed and gas exchange over the ocean, J. Geophys. Res., 97, 7373-7382, 1992.

Weiss, R. F. and Price, B. A.: Nitrous oxide solubility in water and seawater, Mar. Chem., 8, 347-359, 1980.

Wiesenburg, D. A. and Guinasso Jr., N. L.: Equilibrium solubilities of methane, carbon monoxide, and hydrogen in water and seawater, J. Chem. Eng. Data, 24, 356-360, 1979.
Zhang, G. L., Zhang, J., Liu, S. M., Ren, J. L., and Zhao, Y. C.: Nitrous oxide in the Changjiang (Yangtze River) estuary and its adjacent marine area: Riverine input, sediment release and atmospheric fluxes, Biogeosciences, 7, 3505-3516, doi:10.5194/bg-73505-2010, 2010.

Zindler, C., Bracher, A., Marandino, C. A., Taylor, B., Torrecilla, E., Kock, A., and Bange, H. W.: Sulphur compounds, methane and phytoplankton: Interactions along a north-south transit in the western Pacific Ocean, Biogeosciences, 10, 3297-3311, doi:10.5194/bg-10-3297-2013, 2013. 